\title{
PRODUCT RANKING: MEASURING PRODUCT REVIEWS ON THE PURCHASE DECISION
}

\author{
Ahmad Johan ${ }^{1)}$, Barkah Rosadi ${ }^{2)}$, Tezza Adriansyah Anwar ${ }^{3)}$ \\ ${ }^{1,2,)}$ Sekolah Tinggi Ilmu Administrasi, Bandung, Indonesia, ${ }^{3)}$ Universitas Jenderal Achmad Yani, Cimahi, Indonesia \\ Corresponding author: ahmad.johan@stiabandung.ac.id
}

\begin{abstract}
The development of the digital world today has had a significant impact on the industrial sector, one of which is the development of e-commerce. E-commerce is one of the platforms used by consumers in searching for information related to the needs of both products or services. Rating of a product plays an important role that can help consumers to support purchasing decisions and reduce search costs. Many factors can influence online purchasing decisions such as ewom, celebrity influencers, and online discounts, but very few studies have examined product ratings in determining purchasing decisions. This study aims to obtain results regarding the effect of product rating and web quality on purchasing decisions among private university students in Bandung. This type of research is an explanatory research that intends to explain the position of the variables studied and the relationship between one variable and another. The sample used in this study was 100 6th semester students with a focus on 3 classes of business and management faculty. The results showed that there was an influence between product rating and web quality variables on purchasing decisions. Although the results show that the effect is not large enough, these two factors, especially product ratings, are one of the variables that are often used by consumers in supporting online purchasing decisions.
\end{abstract}

Keywords: Product ranking, web quality, purchasing decisions

\section{Introduction}

Marketing management experts claim that the success of a company is largely determined by the strategy adopted (Fan et al., 2018). Currently the development of the internet has led to an explosion of product choices faced by consumers, making it easier for consumers to search for products or services (Ursu, 2018). The role of technology in industrial progress today has become a factor that affects business continuity. In order to increase the company's competitiveness and process its strategic plan, the company must have quality products and services (Agag, 2019; Sullivan, 2018). Currently, e-commerce businesses always provide an opportunity to assess a product and service. In contrast to conventional businesses, which judge a product or service only unilaterally, namely from the seller. A rating can help consumers to rate a product when they want to make a purchase (Anisah, 2018). According to Mou, (2020) this can lower consumer search costs. Today's cellular devices have become tools where consumers search for information related to the products and services they need and can establish interactions between customers and providers. In Indonesia, there are various kinds of e-commerce platforms that are tools to meet the needs of today's consumers, this can be seen in table 1:

Table 1. Percentage of e-commerce users

\begin{tabular}{lc}
\hline \multicolumn{1}{c}{ Name } & Percentage \\
\hline Shopee & $45 \%$ \\
\hline Tokopedia & $25 \%$ \\
\hline Buka lapak & $20 \%$ \\
\hline Lazada & $10 \%$ \\
\hline
\end{tabular}

Based on table 1, the shopee platform is in the first place and lazada is in the last order. This shows that not all platforms have the same quality. Based on the results of interviews with 5 users, many consumers are disappointed with Lazada's products and services so that many find bad ratings. Likewise with the quality of the web that must be improved. One of the obstacles often faced by consumers is the incompatibility of goods with those ordered, delivery delays, and difficulties in using the application due to the large number of menus on the web, and the lack of response (Suryani \& Rosalina, 2019). Currently in the digital era, it does provide convenience with various existing technologies (Tezza, 2020), but not all technologies, especially online shopping applications, provide convenience and trust to consumers. Product rating is one of the most frequently used methods by consumers before making a purchase (Ursu, 2018). Previous research has used product reviews as an alternative in making decisions (Bhamre, 2017; Z. Fan, 2018; Guan, 2019), but there are still few studies that use the product rating feature in making purchasing decisions, especially on skin care products. Many complaints are expressed by consumers, especially women regarding the incompatibility of the product ordered with the product received. High rating products can be used as an assessment for consumers in making purchases. In addition to product ratings, research by Rendy, P and Handoko (2020) 
states that good web quality can have an influence on consumer decisions. In the context of online shopping, website visibility and design play an important role in building consumer trust. Because the relationship between buyers and sellers in online transactions is mediated by the website. A quality website is one that has convenience, security, and good design.

Bandung is one of the big cities in Indonesia, is one of the cities of education and also the city of universities (Wardoyo, W \& Andini, 2017), and contributes to the development of the world of education. University $\mathrm{X}$ is one of the universities located in the city of Bandung with 5 faculties (economics and management, industrial engineering, informatics engineering, language and design). Given that there are a large number of students at the University, this research is focused on one faculty (economics and management) by focusing on 3 classes in semester 6 . The purpose of this study was to obtain the results of research on product rating and web quality and how much influence it has on purchasing decisions on skin care products among private university students in Bandung.

\section{Literature Review Product Rating}

A product rating is a codified summary of opinions and ratings on a standard scale (that is, the number of stars), which is a convenient way for potential customers to form product impressions. The results of existing research indicate that online product ratings have a significant impact on consumer purchasing decisions keputusan (Hossin, 2019). When a consumer wants to buy some product (such as a cell phone, car, or other product), he usually pays attention to several product candidates and online ratings on those products. Until now, studies on online product ranking are still relatively rare. Fan, et al (2014) mention that several important attributes in product ranking (eg, average rating, participant popularity, number of participants) were identified based on online social ranking networks, and calculated based on the identified attributes. On this basis, product ratings can be determined according to product affinity. Li et al. (2014) built a comprehensive evaluation model for ranking online products. In study Fan et al (2018) It is assumed that some important features of the product type are first identified by the consumer, and then, the product rating value can be obtained using the theory of social network analysis. According to the rating value, the product rating can be determined. Ursu, (2018) assessed that online product ratings can directly influence purchasing decisions.

H1. Product rating has a significant effect on purchasing decisions

\section{Web Quality}

The concept of website quality has attracted great attention to researchers and industry practitioners. Website quality is defined as the overall excellence or effectiveness of [website] in conveying the intended message to customers (Rose et al., 2012). Chan, T (2015) defines it as the user's evaluation of whether the website features meet the user's needs and reflect the overall advantages of the website. As quoted by Wijaya et al., (2018) Service provider websites with online retail stores must rely on various website attributes to make purchasing decisions. In addition, Chan, T Park (2015) suggested that online social network members will repurchase through websites that they are emotionally connected to. Widespread internet users, especially in the context of e-commerce, a quality web must be able to provide information for consumers in order to make decisions. Aren et al., (2013) mentions several dimensions in measuring web quality, including information that is relevant, reliable, and provides security to users (Wijaya et al., 2018). Every online store must be able to provide relevant information to consumers and respond quickly to any requests that can meet their needs. Although not face to face directly, the quality of the web can be an intermediary that can influence consumers in making purchases (Lim et al., 2020).

$\mathrm{H} 2$. Web quality has a significant effect on purchasing decisions.

\section{Buying Decision}

According to Kotler, P (2017) Purchase decision is an integration process that combines knowledge to evaluate two or more alternative options and choose one of them. If someone does not choose from various alternatives then it is not a decision. In making purchasing decisions, consumers can form six sub-decisions; product, brand, dealer, quantity, time and payment method (Cengiz, 2017). According to Widodo, (2017) Purchase decision is the stage of consumer evaluation of forming preferences between the most preferred brands. A marketer needs to understand how the buying decision process occurs in order to determine his business strategy (Wang, 2018). The decisions taken by consumers will be closely related to what they buy, including products or services, the number of purchases, where to buy, when to buy and how to buy. (Pratminingsih, 2019). Decision is defined as the selection of available options (Kotler, 2017). In the context of e-commerce, a decision can be influenced by reviews on the seller's website or application. Product reviews listed on the application can be used as a tool in the context of decision making. In addition, research Wijaya et al., (2018) also mentioned that the quality of the web can have an influence on decisions. This is because convenience and security are a measure of decision making.

H3. Product rating and web quality significantly influence purchasing decisions 


\section{Research Method}

This type of research is an explanatory research that intends to explain the position of the variables studied and the relationship between one variable and another. In this study, the researcher distributed a questionnaire questionnaire online by distributing a network link that would direct the object to a page that displayed several questionnaire questions. Next, the researcher selected objects that only used the Lazada application. The population in this study were 3 classes in semester 6 as many as 134 female female students who used online applications to purchase skin care. Then the sample was selected using the slovin formula so that 100 samples were selected incidentally which were considered to have matches (Malhotra. K, 2019). The data collection methods used in this study are observation, interviews and questionnaires using a Likert scale of 1 to 5 . A questionnaire is said to be valid if the questions on the questionnaire are able to reveal something to be measured. The validity and reliability tests in this study show that each statement item in this study has a Sig alpha level 0.05 level, meaning that the research variable is valid. The reliability test showed that each question in the variable obtained a significance value above 0.6, meaning that each instrument was said to be reliable.

\section{Result and Discussion \\ Profil Respondent}

This research was conducted at a private university in Bandung, West Java, using students from the economics and business faculties as respondents. This study uses a descriptive method with a quantitative approach by distributing questionnaires. Calculation of the sample using iteration formula with the number of respondents as many as 100 people. The sampling technique in this study is non-probability sampling with incidental sampling. Sources of data obtained in the study in the form of secondary and primary data.

Table 2. Descriptive Analysis

\begin{tabular}{lcc}
\hline \multicolumn{1}{c}{ Variable } & Ave rage \% & Category \\
\hline Product rating & 79,64 & Good \\
\hline Web quality & 73,64 & Good \\
\hline Purchasing decision & 74,21 & Good \\
\hline Source: Processed data $(2021)$ & &
\end{tabular}

Source: Processed data (2021)

Of the 100 data analyzed, the majority of female students have become users of online applications in making purchases. Almost every day, students make transactions using online applications to find their needs. When a consumer wants to buy several products, he usually pays attention to several product candidates to be searched for and sees online product ratings on these products. However, not all consumers can choose the desired product due to the large number of products. Therefore, to support consumer purchasing decisions, a product rating method based on online ratings is needed. A good quality web is a web that provides convenience and good interaction relationships. According to the concept Lim et al., (2020), applications or web can be intermediaries in interacting between customers and providers, so that if the quality of the web is good then consumers will feel comfortable in finding information about the product or service to be selected. So that in table 1, each variable shows that the average percentage of each variable is in the good category.

\section{Test the Effect of Product Rating and Web Quality on Purchase Intention}

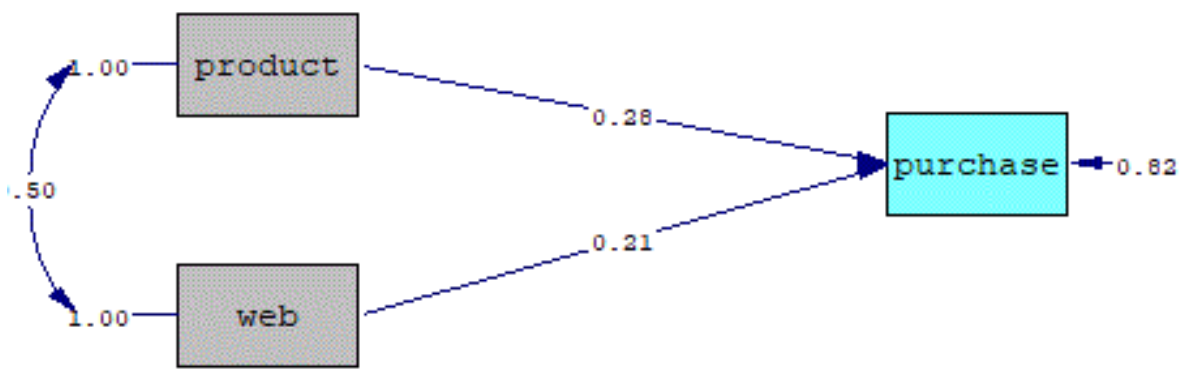

Figure 2. Path Diagram

Purchase $=0.280 *$ product $+0.212 *$ web, Errorvar. $=0.818, \mathrm{R}^{2}=0.182$

$\begin{array}{lccc}\text { Standerr } & (0.105) & (0.105) & (0.117) \\ \text { Z-values } & 2.656 & 2.014 & 7.000 \\ \text { P-values } & 0.008 & 0.044 & 0.000\end{array}$


From the structural equation above, the hypothesis testing are as follows:

Table 3. Hypothesis Testing

\begin{tabular}{lcccc}
\hline \multicolumn{5}{c}{ Simultaneous Test } \\
\hline \multicolumn{1}{c}{ Null Hipothesis } & F $_{\text {count }}$ & $\mathbf{F}_{\text {table }}$ & Result & Conclussion \\
\hline $\begin{array}{l}\text { Product ranking and web quality do } \\
\text { not have significant impact on } \\
\text { purchasing decision }\end{array}$ & 10,79 & 3,09 & $\mathrm{~F}_{\text {count }}>\mathrm{F}_{\text {table }}$ & $\begin{array}{l}\text { Product ranking and web } \\
\text { quality have significant } \\
\text { impact on purchasing decision }\end{array}$ \\
\hline
\end{tabular}

\begin{tabular}{lcccl}
\hline \multicolumn{1}{c}{ Pull Hipothesis } & $\mathbf{t}_{\text {count }}$ & $\mathbf{t}_{\text {table }}$ & Result & \multicolumn{1}{c}{ Conclussion } \\
\hline $\begin{array}{l}\text { Product ranking does not have } \\
\text { significant impact on purchasing } \\
\text { decision }\end{array}$ & 2,656 & 1,98 & $\mathrm{t}_{\text {count }}>\mathrm{t}_{\text {table }}$ & $\begin{array}{l}\text { Product ranking has } \\
\text { significant impact on } \\
\text { purchasing decision }\end{array}$ \\
\hline $\begin{array}{l}\text { Web quality does not have } \\
\text { significant impact on purchasing } \\
\text { decision }\end{array}$ & 2,014 & 1,98 & $\mathrm{t}_{0}$ rejected $>\mathrm{t}_{\text {table }}$ & $\begin{array}{l}\text { Web quality has significant } \\
\text { impact on purchasing decision }\end{array}$ \\
\hline
\end{tabular}

The table above shows that product ratings and web quality have a significant effect on purchasing decisions. This shows that the two variables have an influence on purchasing decisions when viewed from the value of $f$ count which is greater than $f$ table. The partial test of the effect of product rating and web quality on purchasing decisions is in the following table:

Table 4. Variables Impact

\begin{tabular}{lccrr}
\hline \multicolumn{1}{c}{ Correlations } & Coefficient & \multicolumn{2}{c}{ Impact } & \multirow{2}{*}{ Total } \\
\cline { 3 - 4 } & & Direct & Indirect & \\
\hline $\begin{array}{l}\text { Product ranking does not have significant impact on } \\
\text { purchasing decision }\end{array}$ & 0,280 & $7,84 \%$ & $2,94 \%$ & $10,78 \%$ \\
\hline $\begin{array}{l}\text { Web quality does not have significant impact on } \\
\text { purchasing decision }\end{array}$ & 0,212 & $4,49 \%$ & $2,94 \%$ & $7,43 \%$ \\
\hline \multicolumn{2}{c}{ Total } & & & $\mathbf{1 8 , 2 1 \%}$ \\
\hline \multicolumn{1}{c}{ Residual Factors } & & $\mathbf{8 1 , 7 9 \%}$ \\
\hline
\end{tabular}

If seen in the table above, $18.21 \%$ is obtained which indicates that the two variables, namely product rating and web quality, have an influence on purchasing decisions, but the results show that the effect is small. This also shows that there are other variables that influence purchasing decisions that are not discussed in this study.

\section{Effect of product rating on consumer purchasing decisions}

In research Ursu, (2018) It is stated that product ratings in the context of online stores become a means of assessment when they want to make a purchase. This also indicates that the product rating reflects customer satisfaction. Basically every product rating can help in obtaining information so that it can support a decision. These results are in line with research Fan et al., (2018) which states that the product rating variable can affect consumer purchases. These results emphasize that descriptive information related to products can form an opinion that can be used as an alternative in the selection. Studi Guan, (2019) has made a significant contribution explaining that in the context of online stores, product ratings are very important for the image of the company itself in providing products or services.

\section{The influence of web quality on consumer purchasing decisions}

In research Megawati, (2019) states that there is a positive relationship between website quality and purchasing decisions. Good web quality is able to provide relevant information and provide security for consumer data. In addition, a website not only provides information, but must be quick to respond to questions or complaints when the product or service does not meet expectations. Because the web is an intermediary that can connect customers and service or product providers. These results are supported by research Wijaya et al., (2018) which states that good web quality can have a direct influence on purchasing decisions.

\section{Effect of product rating and web quality on purchasing decisions}

Rating is part of a review that uses the form of a star symbol and comments given in expressing opinions from customers (Wijaya et al., 2018). Product rating can be interpreted as an assessment from users of their experience which refers to the psychological and emotional state they experience when interacting with 
products mediated by web or applications. (Hajek, 2018). Understanding how people make online purchasing decisions is increasingly important. Overall, e-commerce is still dominated by younger consumers who are intense in making purchases. The Internet has become a platform that facilitates the electronic communication of customers in searching for information (Wang, B, 2018). This information can be one of the reasons why consumers make purchases. These results are supported by research Liang, (2018) which states that product ratings listed on the application or web can influence purchasing decisions. Likewise with the results of research Guan, (2019) that regardless of product rating, good web quality can influence consumers in making decisions.

\section{Conclusion}

This study aims to determine the effect of product rating and web quality on consumer purchasing decisions on the use of the Lazada application. The sample in this study were students of the faculty of business and management at a private university in the city of Bandung. The results show that in this case the product rating is used by consumers as a tool in making purchases. If the product rating is good, then consumers are not looking for too much information in making a purchase. Currently, there are many problems that occur in online ordering, one of which is the incompatibility of the goods ordered with the image display on the website or application. Here a quality web plays an important role as a means of intermediary between consumers and sellers. Good web quality is an indicator for consumers to make purchases. For example, if the quality of the web is poor, it is likely that what is traded on the web has an indication of fraud. Therefore, e-commerce companies must always pay attention to the web of their products in the form of applications that are owned in order to maintain the safety and comfort of consumers in finding information related to products and services.

\section{References}

Agag, G. (2019). E-commerce Ethics and Its Impact on Buyer Repurchase Intentions and Loyalty: An Empirical Study of Small and Medium Egyptian Businesses. Journal of Business Ethics, 154(2), 389410. https://doi.org/10.1007/s10551-017-3452-3

Anisah, R. (2018). Role of Trust, Customer Satisfaction, and Perceived Effectivenes of E-Commerce Institutional Mechanism to Repurchase Intention: Systematic Literature Review. In Journal of Physics: Conference Series (Vol. 1060, Issue 1). https://doi.org/10.1088/1742-6596/1060/1/012041

Aren, S., Güzel, M., Kabadayı, E., \& Alpkan, L. (2013). Factors Affecting Repurchase Intention to Shop at the Same Website. Procedia - Social and Behavioral Sciences, 99, 536-544. https://doi.org/10.1016/j.sbspro.2013.10.523

Bhamre, N. (2017). Aspect rating analysis based product ranking. In Proceedings - International Conference on Global Trends in Signal Processing, Information Computing and Communication, ICGTSPICC 2016 (pp. 197-202). https://doi.org/10.1109/ICGTSPICC.2016.7955297

Cengiz, H. (2017). Effect of the need for popularity on purchase decision involvement and impulse-buying behavior concerning fashion clothing. Journal of Global Fashion Marketing, 8(2), 113-124. https://doi.org/10.1080/20932685.2016.1257358

Chan T, Park Y (2015) Consumer search activities and the value of ad positions in sponsored search advertising. Marketing Sci. 34(4): 606-623.

Fan, Z. (2018). Supporting consumer's purchase decision: a method for ranking products based on online multi-attribute product ratings. Soft Computing, 22(16), 5247-5261. https://doi.org/10.1007/s00500-0172961-4

Fan, Z. P., Xi, Y., \& Liu, Y. (2018). Supporting consumer's purchase decision: a method for ranking products based on online multi-attribute product ratings. Soft Computing, 22(16), 5247-5261. https://doi.org/10.1007/s00500-017-2961-4

Guan, C. (2019). Product Rating Statistics as Consumer Search Aids. Journal of Interactive Marketing, 48, 51-70. https://doi.org/10.1016/j.intmar.2019.02.003

Hajek, P. (2018). Initial ratings of different types of e-cigarettes and relationships between product appeal and nicotine delivery. Psychopharmacology, 235(4), 1083-1092. https://doi.org/10.1007/s00213-0174826-Z

Hossin, M. A. (2019). Influence of picture presence in reviews on online seller product rating: Moderation role approach. KSII Transactions on Internet and Information Systems, 13(12), 6097-6120. https://doi.org/10.3837/tiis.2019.12.017

Kotler, P (2017) Marketing: An Introduction. Pearson

Liang, X. (2018). Selecting products considering the regret behavior of consumer: A decision support model based on online ratings. Symmetry, 10(5). https://doi.org/10.3390/sym10050178

Lim, X. J., Cheah, J. H., Waller, D. S., Ting, H., \& Ng, S. I. (2020). What s-commerce implies? Repurchase intention and its antecedents. Marketing Intelligence and Planning, 38(6), 760-776. https://doi.org/10.1108/MIP-03-2019-0145

Li Y, Wu C, Luo P (2014) Rating online commodities by considering consumers'purchasingnetworks. ManagDecis 52(10):2002-2020 
Megawati, Y. (2019). Pengaruh Kualitas Website Terhadap Keputusan Pembelian Layanan Pemesanan Kamar Hotel Pada Situs Traveloka. Journal FAME: Journal Food and Beverage, Product and Services, Accomodation Industry, Entertainment Services, 1(2). https://doi.org/10.30813/fame.v1i2.1426

Mou, J. (2020). International buyers' repurchase intentions in a Chinese cross-border e-commerce platform: A valence framework perspective. Internet Research, 30(2), 403-437. https://doi.org/10.1108/INTR-062018-0259

Malhotra, K (2019) Marketing Research: An Applied Orientation, 7th edition. Pearson.

Pratminingsih, S. A. (2019). The influence of electronic word of mouth and brand image on buying decision. Journal of Advanced Research in Dynamical and Control Systems, 11(3), 995-1002. https://www.scopus.com/inward/record.uri?partnerID=HzOxMe3b\&scp=85069503111\&origin=inward

Rose, S., Clark, M., Samouel, P., \& Hair, N. (2012). Online Customer Experience in e-Retailing: An empirical model of Antecedents and Outcomes. Journal of Retailing, 88(2), 308-322. https://doi.org/10.1016/j.jretai.2012.03.001

Rendy Putra Pradwita, R. B., Handoko, Y., \& Rachmawati, I. K. (2020). PENGARUH KEPERCAYAAN, KEMUDAHAN, DAN KUALITAS INFORMASI PADA WEBSITE WWW.LAROSLAPTOP.COM TERHADAP KEPUTUSAN PEMBELIAN ONLINE. Jurnal Apresiasi Ekonomi, 8(2), 212-220.

Sullivan, Y. W. (2018). Assessing the effects of consumers' product evaluations and trust on repurchase intention in e-commerce environments. International Journal of Information Management, 39, 199-219. https://doi.org/10.1016/j.ijinfomgt.2017.12.008

Suryani, S., \& Rosalina, S. S. (2019). Pengaruh Brand Image, Brand Trust, Dan Kualitas Layanan Terhadap Keputusan Pembelian Ulang Dengan Kepuasan Konsumen Sebagai Variabel Moderating. Administrasi Bisnis, Fakultas Ekonomi Dan Bisnis, Universitas 17 Agustus 1945 Jakarta, 04(1), 41-53.

Tsekouras, D. (2017). The effect of rating scale design on extreme response tendency in consumer product ratings. International Journal of Electronic Commerce, 21(2), 270-296. https://doi.org/10.1080/10864415.2016.1234290

Tezza, A, Kurniawan, Sutrisno, and Anik, S (2020) Student intention to use telkomsel cash (T-cash). journal of business studies and management review (JBSMR), vol 4 No.1.

Ursu, R. M. (2018). The power of rankings: Quantifying the effect of rankings on online consumer search and purchase decisions. Marketing Science, 37(4), 530-552. https://doi.org/10.1287/mksc.2017.1072

Wang, B. (2018). Review rating prediction based on user context and product context. Applied Sciences (Switzerland), 8(10). https://doi.org/10.3390/app8101849

Wang, J. (2018). The Impact of Service Value on Customer Buying Decisions of Product-Service Portfolios. In 2018 15th International Conference on Service Systems and Service Management, ICSSSM 2018. https://doi.org/10.1109/ICSSSM.2018.8465004

Widodo, A. (2017). How E-marketing and trust influence online buying decision: A case study of mataharimall.com in Bandung. Pertanika Journal of Social Sciences and Humanities, 25, 107-114. https://www.scopus.com/inward/record.uri?partnerID=HzOxMe3b\&scp=85051431218\&origin=inward

Wijaya, R., Farida, N., \& Andriyansah. (2018). Determinants of repurchase intentions at online stores in Indonesia. International Journal of E-Business Research, 14(3), 95-111. https://doi.org/10.4018/IJEBR.2018070106

Wardoyo, W., \& Andini, I. (2017). FAKTOR-FAKTOR YANG BERPENGARUH TERHADAP KEPUTUSAN PEMBELIAN SECARA ONLINE PADA MAHASISWA UNIVERSITAS GUNADARMA. Jurnal Manajemen Dayasaing, 19(1), 12. 